\title{
SHADING AND PERIODS OF ACCLIMATIZATION OF MICROPROPAGATED BANANA PLANTLETS CV. GRANDE NAINE
}

\author{
Ciro Scaranari ${ }^{1 *}$; Paulo Ademar Martins Leaf; Paulo Mazzafera ${ }^{3}$ \\ 'Embrapa Transferência de Tecnologia, Av. André Tosello, 209 - Cidade Universitária “Zeferino Vaz”, C.P. \\ 6062 - 13083-970 - Campinas, SP - Brasil. \\ ${ }^{2}$ UNICAMP/FEAGRI - CITP, B. Geraldo, C.P. 6011 - 13083-970 - Campinas, SP - Brasil. \\ ${ }^{3}$ UNICAMP/IB - Depto. de Fisiologia Vegetal, B. Geraldo, C.P. 6109 - 13083-970 - Campinas, SP - Brasil. \\ *Corresponding author <ciro@campinas.snt.embrapa.br>
}

\begin{abstract}
Banana plantlets obtained by micropropagation need to be submitted to a period of acclimatization since they do not use light, water, and nutrients in an efficient way. The acclimatization must be carried out under greenhouse conditions where temperature, light, and air humidity are adequate for a gradual hardening of the plantlets. In this study, the development of banana plantlets was evaluated during acclimatization under a full light condition including covered surfaces with red shade cloth $(70 \%, 50 \%$, and $30 \%$ shade) and black shade cloth (50\% shade), both under a transparent plastic film of $100 \mu \mathrm{m}$. Temperature, relative air humidity, irrigation, and nutrition conditions were also controlled. Physical and physiological parameters were recorded at various stages in the greenhouses after three, six, and nine weeks and also after seven weeks of transplanting to field conditions. Treatments were hierarchically graded according to their statistic classification. Combined results indicated superior outcomes of plantlets maintained under black 50\% shade cloth for nine weeks, both in the summer and winter seasons. Similar results, but in a shorter time, were obtained with plantlets cultivated under red $70 \%$ shade cloth, for six weeks in the summer.

Key words: Musa sp., greenhouse shading, greenhouse climate, ranking
\end{abstract}

\section{SOMBREAMENTO E PERÍODOS DE ACLIMATIZAÇÃO DE MUDAS MICROPROPAGADAS DE BANANEIRA CV. GRANDE NAINE}

\begin{abstract}
RESUMO: Após a sua obtenção em laboratório, mudas in vitro necessitam passar por um período de aclimatização, pois na fase em que se encontram não realizam eficientemente a absorção de luz, água e nutrientes, devendo ser feita em ambiente protegido, onde as condições de temperatura, umidade e luminosidade são favoráveis a um gradual endurecimento das plântulas. No presente trabalho estudouse o desenvolvimento das mudas de bananeira (Musa sp.) durante o segundo estágio da aclimatização (a partir de $10 \mathrm{~cm}$ de altura) sob condições de luminosidade (plena, 70, 50 e 30\% de superfície de cobertura com malha vermelha e 50\% com malha preta, ambas sob filme plástico transparente de $100 \mu \mathrm{m}$ ) associadas a períodos de aclimatização (três, seis e nove semanas), em ambientes com temperatura, umidade do ar, nutrição e irrigação controladas, sendo avaliadas sob variáveis físicas e bioquímicas. Imediatamente após cada período, as plantas foram submetidas a ensaios de campo por sete semanas, sendo avaliadas sob as mesmas variáveis. Na comparação entre as médias, cada tratamento recebeu pontuações obedecendo a ordenação hierárquica de desempenho, segundo critérios de classificação estatística onde se considera o número de tratamentos estatisticamente inferiores e superiores. Nesta ordenação, o uso de tela de malha preta com $50 \%$ de sombreamento associado ao período de nove semanas foi o que propiciou melhores condições, tanto no verão quanto no inverno. Visando a redução para seis semanas, o uso alternativo de tela de malha vermelha com $70 \%$ produz efeitos equivalentes ao da malha preta com $50 \%$, apenas para condições de verão.

Palavras-chave: Musa sp., casas de vegetação - sombreamento, casas de vegetação - clima, ranqueamento
\end{abstract}

\section{INTRODUCTION}

Banana plantlet (Musa sp.) acclimatization can be divided into two phases. In the first, in vitro plantlets are transferred to controlled environments (green- house or box shade, under the conditions of 20 to $28^{\circ} \mathrm{C}, 80$ to $90 \% \mathrm{RH}$, and $70 \%$ shade cloth) for a three to six-week period. In the second phase, plantlets are shifted to trays, pots or bags, under $50 \%$ shade, in a temperature range from $18^{\circ} \mathrm{C}$ to $34^{\circ} \mathrm{C}$, and a relative 
humidity higher than $75 \%$, for a gradual hardening (Souza et al., 1997; Hoffmann, 2002). When plantlets reach $25-30 \mathrm{~cm}$ height they are considered acclimated and become available to the market (Silva et al., 1999).

During plant acclimatization under gradual light intensity, leaves present a darker green color due to mesophyll cell differentiation and increases in pigment content (Sandoval et al., 1994). Alterations in synthesis and degradation of pigments (Donnelly \& Vidaver, 1984; Zaffari et al., 1998) and increases in chlorophyll with the reduction of sun light (Israeli et al., 1995) are also verified. Increases in chlorophyll content are observed depending on the environmental conditions during acclimatization (Pospisilová et al., 1999). Environments with 50 to $60 \%$ shading for three to six weeks and with a fine atomization system with water during the first week are required in the first phase, decreasing by 30 to $50 \%$ in the second phase (hardening) during acclimatization of micropropagated banana plantlets $\mathrm{cv}$. Grande Naine (Marie, 1995). Light intensity is controlled with black shade clothes, in a linear way only, through the light spectrum, i.e., no differences in transmittance in the PAR range. Colored shade clothes aim to combine physical protection and light filtering, resulting in vegetative growth, productivity, precocity, quality, and maturation velocity gains for apple and peach trees (Shahak et al., 2004). The objective of the present work was to evaluate the development of micropropagated banana plantlets under different shading intensities and periods of acclimatization (or hardening), under fixed temperature and relative humidity air conditions.

\section{MATERIAL AND METHODS}

The experiment was installed in Campinas, SP, Brazil (22 $48^{\prime} \mathrm{S}, 47^{\circ} 03^{\prime} \mathrm{W}, 640 \mathrm{~m}$ asl). The summer period was considered from December to April, 2005, while the winter period from June to October, 2005. Micropropagated Grande Naine plantlets measuring 10 to $12 \mathrm{~cm}$ height, ex-vitro pre-acclimated, and maintained under $70 \%$ shading, 20 to $25^{\circ} \mathrm{C}$, and Relative Humidity (RH) higher than $80 \%$, for four to six weeks, was the experimental material.

Five mini-tunnel greenhouses were installed in an east-west orientation $(2.0 \mathrm{~m}$ width, $10.5 \mathrm{~m}$ length, and $2.0 \mathrm{~m}$ total height) with a $2.0 \mathrm{~m}$ spacing among them, externally covered with $0.1 \mathrm{~mm}$ width Low Density Polyethylene Film - LDPF, complemented against ultraviolet radiation (UV) and internally, in four of them, with different shade clothes, where incident radiation interception values were determined by a spectro radiometer with the accessory "External Integrating Sphere." Transmittance values through the spectrum are shown in Figure 1, according to the following de- scription: E1 - Environment 1: Red 70 shade cloth, with shading of Photosynthetically Active Radiation - PAR - range (400 to $700 \mathrm{~nm}$ ) of $69.92 \%$; E2 - Environment 2: Black 50 plastic shade cloth, with $57.77 \%$ PAR shading; E3 - Environment 3:Red 50 shade cloth, with 50.73\% PAR shading; E4 - Environment 4: No shade, using only a LDPF film covering with $12.74 \%$ PAR shading; E5 - Environment 5: Red 30 shade cloth, with $29.73 \%$ PAR shading.

Each environment had a workbench of 6.24 $\mathrm{m}$ length, $2.0 \mathrm{~m}$ width, and $2 \mathrm{~cm}$ thickness, with 24 trays placed over each one (three per block) with 24 plantlets each, placed in the center of the structure and with $2.13 \mathrm{~m}$ limit from its east and west extremities, a large enough distance to avoid the direct sunlight incidence (Leal, 2003), totalizing 576 plantlets (192 belonging to treatments).

For water and nutrient supply (eight mist sprayers $40 \mathrm{~L} \mathrm{~h}^{-1}$ by $2.5 \mathrm{kgf} \mathrm{cm}^{-2}$ ) two daily irrigations of $0.024 \mathrm{~L}$ per plant were performed with pure water and, after every $6^{\text {th }}$ mist spray fertirrigations were applied, alternating MAP (monoammoiumphosphate), calcium nitrate, and potas-

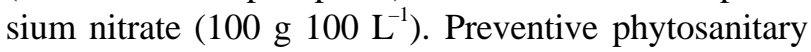
treatments were also made every 15 days with

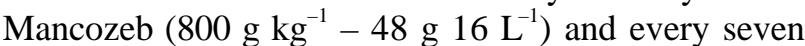
days with Deltamethrin $\left(25 \mathrm{~g} \mathrm{~L}^{-1}-50 \mathrm{~mL} 100 \mathrm{~L}^{-1}\right.$ of water).

Temperature was controlled with five pad fan evaporative coolers (one for each environment) at 28/ $25^{\circ} \mathrm{C}(\mathrm{On} / \mathrm{Off})$, and humidity was controlled with day nebulization (6 seconds intermittence every $40 \mathrm{sec}-$ onds). Aiming to keep the relative air humidity at the desired levels, a nebulization system (five lines with five fog systems each, $7 \mathrm{~L} \mathrm{~h}^{-1}, 4 \mathrm{kgf} \mathrm{cm}^{-2}$ ) was installed. Dry and wet bulb air temperatures were monitored by three aspirated psychrometers installed in each greenhouse connected to a data acquisition system for daily reads in a 60 seconds partition. Figure 2 shows each environment with all above cited systems.

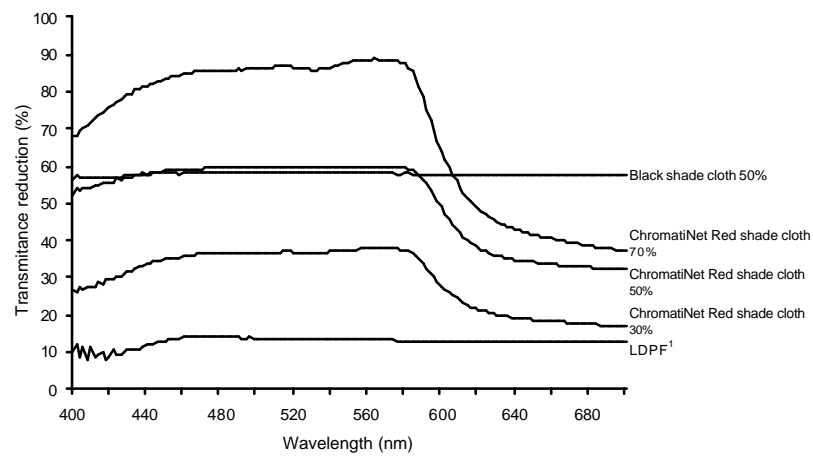

Figure 1 - Shading provided by the shade nets obtained with a spectroradiometer LI-1800 in the PAR range. LPDF ${ }^{1}$ = Low Density Polyethylene Film 

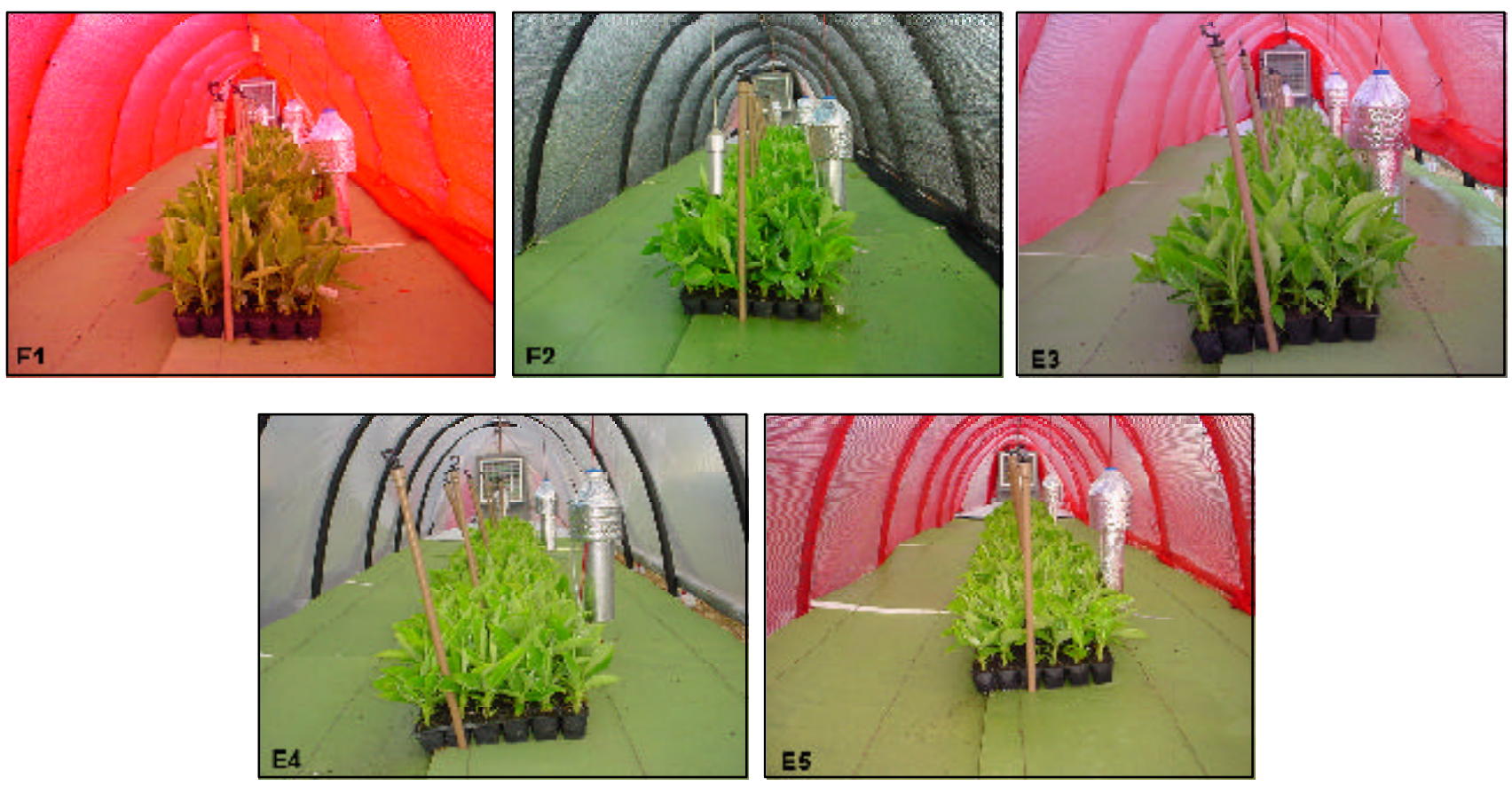

Figure 2 - Internal view of each environment with all installed systems.

Light intensity measurements with two sensors (for PAR and total solar radiation measurement) connected to another data acquisition system were made in two distinct insulation situations (open and cloudy sky) at $9 \mathrm{~h} 00,12 \mathrm{~h} 00$, and $15 \mathrm{~h} 00$, for three days randomly chosen throughout the course of the experiment. For external environment comparison, another identical set was simultaneously installed outside each environment. Instantaneous data on the irradiance simultaneously inside and outside the greenhouses is related by Frisina et al. (2000).

Distinct acclimatization periods were studied as follows: P1 - Period 1: Three weeks counted from the tray division and the beginning of the acclimatization process in each environment. Acclimatization beginning on 12/15/04 and ending on 01/06/05 (summer experiments) and from 06/22/05 to 07/13/05 (winter experiments); P2 - Period 2: Six weeks, from 12/15/04 to $01 / 27 / 05$ (summer experiments) and from $06 / 22 / 05$ to 08/03/05 (winter experiments); P3 - Period 3: Nine weeks, from 12/15/04 to 02/17/05 (summer experiments) and from 06/22/05 to 08/24/05 (winter experiments). On days $21^{\text {st }}(\mathrm{P} 1), 42^{\text {nd }}(\mathrm{P} 2)$ and $63^{\text {rd }}(\mathrm{P} 3)$, out of the eight useful plants of each experimental parcel, three were designated for development analyses (Figure 3), according to the description that follows.

Two useful plantlets were removed from the substrate for the following physical determinations: $\mathrm{PH}$ - plant height (starting from the plantlet base to the vertex of the hem of the most recently open leaf; PD
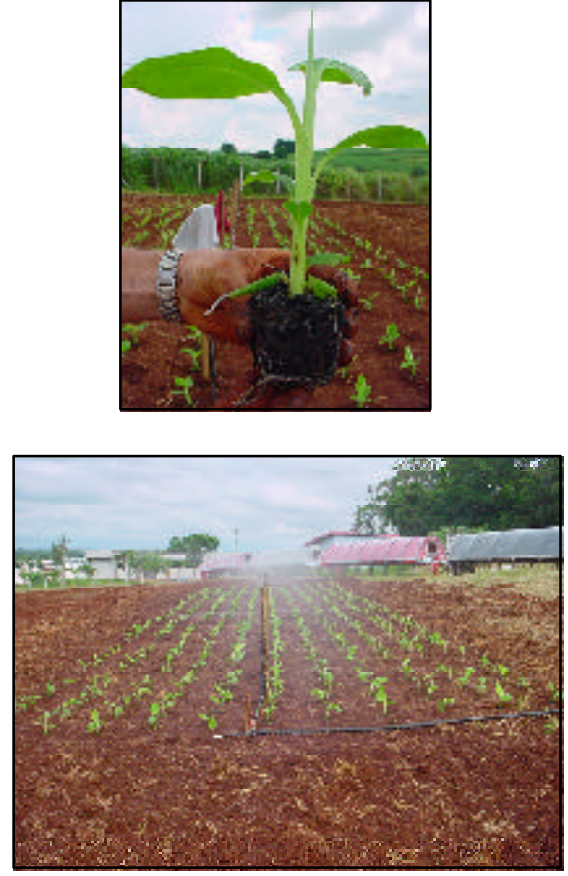

Figure 3 - Plants in the field.

- diameter at the base of the pseudostem; NL - number of expanded leaves; LA - leaf area, using the software SIARCS ${ }^{\circledR}$ (Jorge \& Crestana, 1996; Vieira-Júnior et al., 1998); RL - root length; fresh mass of the "aerial part" portion (FMAP), of the rhizome portion (FMRI) and root portion (FMRO).

The last two useful plants were destined to the following biochemical determinations: TSS - Total Soluble Sugars (McCready et al., 1950; Dubois et al., 
1956); TCL - total chlorophyll ( $a$ and $b$ values) and CXC - carotenoids and xanthophylls (Lichtenthaler, 1987); Y - chlorophyll fluorescence by a Photosynthesis Yield Analyzer represented by the "Yield" factor, which is the relation between presented fluorescence and that estimated for non saturated light (Genty et al., 1989).

Immediately after each period, three experiments for plantlet development in field conditions were installed by random casualizated blocks. Each one with five treatments (environments), eight blocks, and three useful plants/parcel spaced $0.5 \mathrm{~m}$ apart as follows: Field 1, constituted only by P1 plants: planted on $01 /$ $07 / 05$ and evaluated at the $49^{\text {th }}$ day, on $02 / 25 / 05$ for summer experiments. For the winter ones, the dates were 07/15/05 and 09/02/05; Field 2, with only P2 plants: from $01 / 28 / 05$ to $03 / 18 / 05$ (summer experiments) and for the winter experiments, the dates were 08/05/05 and 09/23/05; Field 3, with only P3 plants: from $02 / 18 / 05$ to $04 / 08 / 05$ (summer experiments) and for winter experiments, the dates were $08 / 26 / 05$ to $10 /$ $14 / 05$.

The planting was made in $15 \mathrm{~cm} \times 15 \mathrm{~cm}$ holes with no fertilization because of the short period available for evaluation. Weeds were controled using two manual weedings. The irrigation misting system (eight devices) supplied a $12 \mathrm{~mm}$ daily lamina (two periods of 30 minutes). The evaluation of the same cited parameters, except for FMRI and FMRO portions, was made on the $49^{\text {th }}$ day (seven weeks), a long enough period for plant establishment in the field.

The statistical analyses were performed in groups using the statistical package $\mathrm{SAS}^{\hat{a}}-8.0$ involving five environments and three periods. Results were submitted to ANOVA and the means compared by the Tukey test $(p<0.05)$. Due to the considerable number of parameters with expected different results and aiming to establish a general evaluation capable of considering all of them together, treatments received points according to a hierarchic performance ordination. A similar classification to that of Caliari \& Silva (2001) was considered, based on the statistical values (statistical classification) used in the classification of corn seed lots, according to applied viability tests. For each variable, the punctuation was represented by the sum of positive or null points (number of statistically inferior treatments) with the negative or null points (number of statistically superior treatments), as a mean of the balance. According to this methodology, initial gains during the acclimatization periods in the greenhouse and the development under field conditions were considered. The influences of each environment, positive or not, could be verified and quantified not only in the acclimatization phase but also in the field.

\section{RESULTS AND DISCUSSION}

The classification obtained among the environments, in both summer and winter experiments (Table 1), indicates worse plantlet performances in less shaded environments (E5 and E4), independently of the considered acclimatization period. These results are in agreement with Silva et al. (1994) who mention sunlight fractioning as a factor that improves the efficiency of acclimatization; Hoffmann (2002) cites the light stress as an important factor, and Pospisilová et al. (1999) mention the occurrence of dessecation and photoinhibition under excess of light.

For an easier visualization and interpretation, Table 3 summarizes the classifications obtained in each of the situations, in which it is possible to verify through the analyses of periods (Table 2), independently of environment and season to which the plantlets were exposed, the three-week period (P1) was systematically inferior to the other ones. The nine-week period (P3) was the best, while the six-week period (P2) presented an intermediary performance, except for the environment E1 in the summer, which only in this case was the best for plant acclimatization.

For the environment analysis (Table 1), E2 (black shade cloth) and E3 (red shade cloth), despite presenting similar shading in their commercial classification, presented a differentiated reduction in transmittance in the PAR range (Figure 1) in which the red shade cloth shows lower reduction under wavelengths from $570 \mathrm{~nm}$, the spectrum range that corresponds to variations from orange to red (Hanan, 1997). Such differentiation was not converted in comparative advantages, since it was always possible to verify the superiority offered by the black shade cloth. Despite the fact that the red shade cloth transmits more radiation in the range from 610 to $720 \mathrm{~nm}$ (strong photosynthetic activity by chlorophyll and carotenoids absorption - Taiz \& Zeiger, 2004) than the black shade cloth (Figure 1), such difference did not promote an increase in the content of these pigments. Instead, E2 plants had contents that were never inferior to those of E3. Likewise, decreases in chlorophyll content are associated to environment stress factors (Hendry \& Price, 1993). This fact was verified during the greenhouse experiments, in which the less shaded surroundings that offer more stressed conditions present lower levels of this pigment.

Considering that the yield variable represents the performance of the effective conversion of photochemical energy in photosynthesis and reflects the general efficiency of this process (Genty et al., 1989), lower quantum yields verified in the less shaded environments can be considered a good indicative of plant stress. 

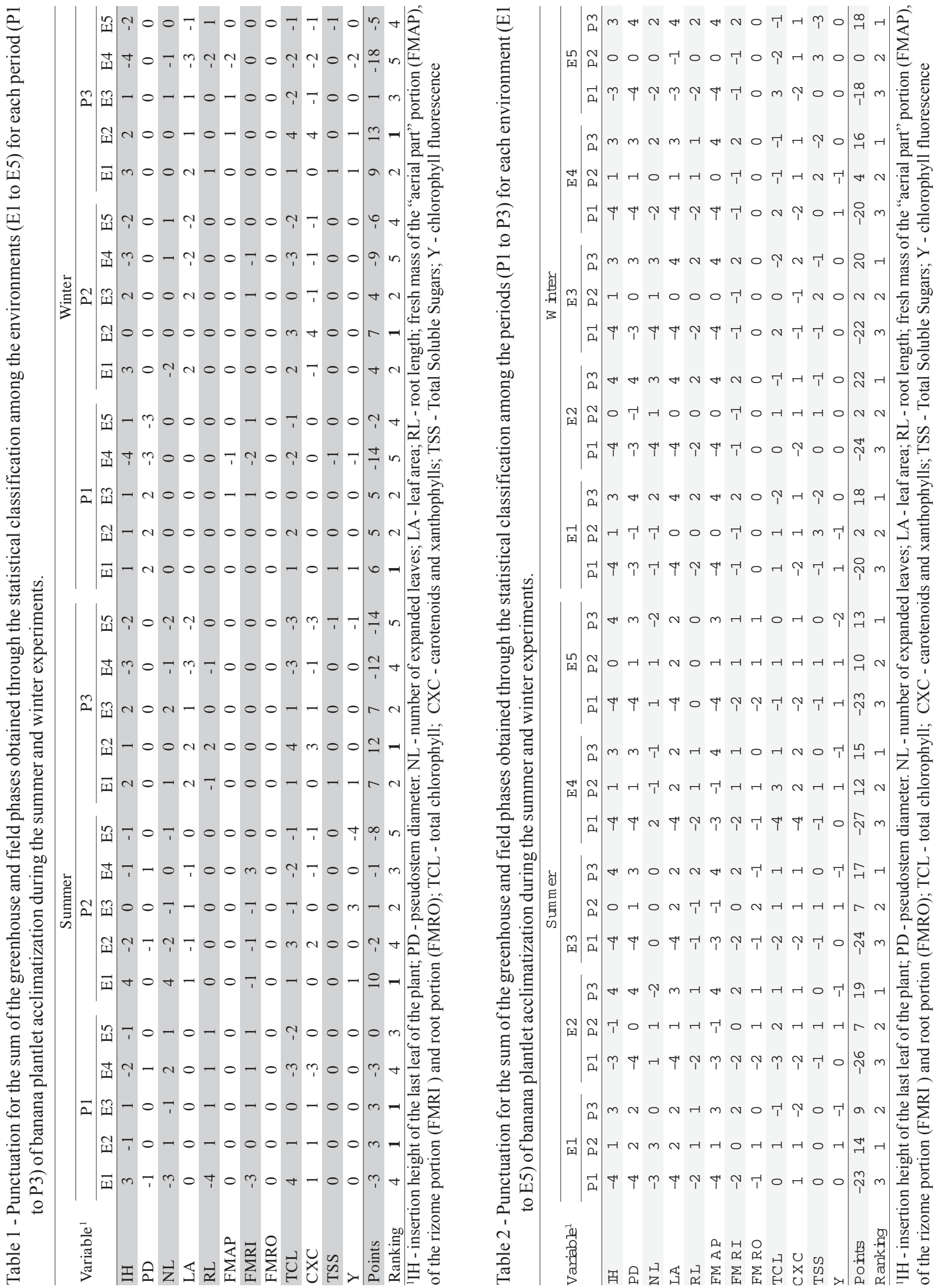
Table 3 - Summary of the statistical classification in the summer and winter (sum of greenhouse and field points) among periods (AP), P1 to P3, and among environments (AE), E1 to E5.

\begin{tabular}{|c|c|c|c|c|c|c|c|c|c|c|c|c|}
\hline \multirow{3}{*}{ Environment } & \multicolumn{6}{|c|}{ Summer periods } & \multicolumn{6}{|c|}{ Winter periods } \\
\hline & \multicolumn{2}{|c|}{$\mathrm{P} 1$} & \multicolumn{2}{|c|}{$\mathrm{P} 2$} & \multicolumn{2}{|c|}{ P3 } & \multicolumn{2}{|c|}{$\mathrm{P} 1$} & \multicolumn{2}{|c|}{$\mathrm{P} 2$} & \multicolumn{2}{|c|}{$\mathrm{P} 3$} \\
\hline & AP & $\mathrm{AE}$ & $\mathrm{AP}$ & $\mathrm{AE}$ & AP & $\mathrm{AE}$ & $\mathrm{AP}$ & $\mathrm{AE}$ & AP & $\mathrm{AE}$ & $\mathrm{AP}$ & $\mathrm{AE}$ \\
\hline E1 & 3 & 4 & 1 & 1 & 2 & 2 & 3 & 1 & 2 & 2 & 1 & 2 \\
\hline E2 & 3 & 1 & 2 & 4 & 1 & 1 & 3 & 2 & 2 & 1 & 1 & 1 \\
\hline E3 & 3 & 1 & 2 & 2 & 1 & 2 & 3 & 2 & 2 & 2 & 1 & 3 \\
\hline E4 & 3 & 4 & 2 & 3 & 1 & 4 & 3 & 5 & 2 & 5 & 1 & 5 \\
\hline E5 & 3 & 3 & 2 & 5 & 1 & 5 & 3 & 4 & 2 & 4 & 1 & 4 \\
\hline
\end{tabular}

The superiority of environment E1, verified during the P2 period in summer, might be an interesting alternative for saving time in the process. However, such superiority has not been confirmed in the winter, which denotes that its comparative advantages are inferior when compared to the influence of lower thermal offer and intensity of incident radiation, common in this season. Discarding the P1 period of three weeks, since it always presented an inferior classification, not only in the summer but also in the winter, the analyses among the red shade cloth environments E1, E3, and E5 permit the establishment of a decreasing gradient of performance, which is in agreement with the information given by Silva et al. (1994), Hoffmann (2002), and Pospisilová et al. (1999).

Finally, it is noteworthy to assert that in none of the treatments there was occurrence of plant death (useful or borders) under any of the conditions, whether greenhouse, field, winter or summer. It is a fact verified by Lisei de Sá \& Braga (2002), who have not found loss in banana plantlets cv. Prata-Anã acclimatization, 3 and $6 \mathrm{~cm}$ tall, which is an inferior range when compared to the initial material used in this work (between 10 and $12 \mathrm{~cm}$ ). Pereira et al. (2005) verified a mortality index of zero and $1.43 \%$ in plants of this cultivar, under shade cloth acclimatization at the $15^{\text {th }}$ and $30^{\text {th }}$ day, respectively; theses indexes are considered low due to the in vitro and ex vitro condition to which the plantlets were submitted (Pospisilová et al., 1999; Sutter, 1998).

\section{CONCLUSIONS}

The use of black 50\% shade cloth during a nine-week period presented the best results for the second phase of acclimatization of micropropagated banana plantlets cv. Grande Naine, under summer and winter conditions. Aiming to reduce the acclimatization phase to six weeks, a red $70 \%$ shade cloth can be used during summer. Lower rank results were found in environments with a $50 \%$ lower shading, being therefore not recommended.

\section{ACKNOWLEDGMENTS}

The authors thank FAPESP for financial support (Processes 03/04216-6; 04/10900-0 e 05/503748) and Embrapa for the Ph.D grant.

\section{REFERENCES}

CALIARI, M.F.; SILVA, W.R. Interpretação de dados de testes de vigor na avaliação da qualidade fisiológica de sementes de milho. Revista Brasileira de Sementes, v.23, p.239-251, 2001.

DONNELLY, D.J.; VIDAVER, W.E. Pigment content and gas exchange of red raspberry in vitro and ex vitro. Journal of the American Society for Horticultural Science, v.109, p.177$181,1984$.

DUBOIS, M.; GILLES, A.; HAMILTON, J.K.; REBERS, P.A.; SMITH, F. Colorimetric method for determination of sugars and related substances. Analytical Chemical, v.28, p.350$355,1956$.

FRISINA, V.A.; ESCOBEDO, J.F.; GOMES, E.N. Estimativa da radiação fotossinteticamente ativa (PAR) em estufa de polietileno. In: ENCONTRO DE ENERGIA NO MEIO RURAL, 3., Campinas, 2000. Proceedings. Available at: http:// www.proceedings.scielo.br/scielo.php?script=sci_arttext\&pid= MSC0000000022000000200056\&lng=en\&nrm=abn. Accessed 18 May 2006.

GENTY, B.; BRIANTAIS, J.M.; BAKER, N.R. The relationship between the quantum yield of photosynthetic electron-transport and quenching of chlorophyll fluorescence. Biochimica et Biophysica Acta, v.990, p.87-92, 1989.

HANAN, J.J. Climate control. In: HANAN, J.J. Greenhouses: advanced technology for protected horticulture. Boca Raton: CRC Press, 1997. chapter 8, p.573-645.

HENDRY, G.A.F.; PRICE A.H. Stress indicators: chlorophylls and carotenoids. In: HENDRY, G.A.F.; GRIME, J.P. (Ed.) Methods in comparative plant ecology. London: Chapman \& Hall, 1993. p.148-152.

HOFFMANN, A. Aclimatação de mudas produzidas in vitro e in vivo. Informe Agropecuário, v.23, p.21-24, 2002.

ISRAELI, Y.; PLAUT, Z.; SCHWARTZ, A. Effect of shade on banana morphology, growth and production, Scientia Horticulturae, v.62, p.25-56, 1995.

JORGE, L.A.C.; CRESTANA S. SIARCS 3.0: novo aplicativo para análise de imagens digitais aplicado a ciência do solo. In: CONGRESSO LATINO DE CIÊNCIA DO SOLO, 13., Águas de Lindóia, 1996. Solo Suelo 96. Campinas: Sociedade Brasileira de Ciência do Solo, 1996. p.5.

LEAL, P.A.M. Radiação solar. In: CURSO ESTUDO DIRIGIDO EM CONSTRUÇÕES RURAIS E AMBIÊNCIA, Campinas: Unicamp/Fea, 2003. 36p. Mimeografado. 
LICHTENTHALER, H.K. Clorophylls and carotenoids: pigments of photosynthetic biomembranes. Methods in Enzymology, v.148, p.350-382, 1987.

LISEI DE SÁ, M.E.; BRAGA, M.F. Avaliação de protocolo para obtenção de mudas micropropagadas de bananeira cv. Prata-anã (subgrupo AAB). Revista Brasileira de Fruticultura, v.24, p.236-239, 2002.

MARIE, P. L'acclimatation des vitroplants de bananiers de Grandee Naine. Fort de France: CIRAD-FLHOR, 1995. 21p. (Fascicules de la Base Centre Bananes Antilles).

McCREADY, R.M.; GUGGOLZ, J.; SILVIERA, V.; OWENS, H.S Determination of starch and amylose in vegetables. Analytical Chemistry, v.22, p.1156-1158, 1950.

POSPISILOVÁ, J.; TICHÁ, I.; KADLECEK, P.; HAISEL, D.; PLZAKOVÁ, S. Acclimatization of micropropagated plants to ex vitro conditions. Biologia Plantarum, v.42, p.481-497, 1999.

SANDOVAL, F.J.; MÜLLER, L.E.; WEBERLING, F. Foliar morphology and anatomy of Musa cv. Grande Naine (AAA) plants grown in vitro and during hardening as compared to fieldgrown plants. Fruits, v.49, p.37-46, 1994.

SHAHAK, Y.; GUSSAKOVSKY, E.E.; COHEN, Y.; LURIE, S.; STERN, R.; KFIR, S.; NAOR, A.; ATZMON, I.; DORON, I.; GREENBLAT-AVRON, Y. ColorNets: a new approach for light manipulation in fruit trees. Acta Horticulturae, v.636, p.609616, 2004.

SILVA, A.T.; PASQUAL, M.; ANTUNES, L.E.C.; CARVALHO, G.R.C. Influência da espécie, desfolha e ambiente na aclimatação de plântulas produzidas "in vitro". Ciência e Prática, v.18, p.280-285, 1994.
SILVA, D.S.; BOSISIO A.; BOSCAROL B.; BELTZER, A.; AMSLER, G.P. Aclimatação de mudas de bananeira (Musa spp.) "Prata"( $\mathrm{AAB}$ ) em diferentes substratos. Revista Ceres, v.46, p.543-554, 1999.

SOUZA, A.S.; DANTAS, J.L.L.; SOUZA, F.V.D.; CORDEIRO, Z.J.M.; SILVA NETO, S.P. Propagação. In: ALVES, E.J. (Org.) A cultura da banana: aspectos técnicos, socioeconômicos e agroindustriais. Cruz das Almas: EMBRAPA-CNPMF, 1997. p.151-195.

SUTTER, E. Stomatal and cuticular water loss from apple, cherry and sweetgum plants after removal from in vitro culture. Journal of the American Society for Horticultural Science, v.113, p.234-238, 1988.

TAIZ, L.; ZEIGER, E. Fisiologia vegetal. 3 ed. Porto Alegre: Artmed, 2004. 719p.

VIEIRA-JÚNIOR, P.A.; DOURADO-NETO, D.; SMIDERLE, O.J.; CICERO, S.M. Efeitos de métodos de irrigação sobre a produção e a qualidade de sementes de feijão. Revista Brasileira de Sementes, v.20, p.100-105, 1998.

ZAFFARI, G.R.; PERES, L.E.P.; KERBAUY, G.B. Endogenous levels of cytokinins, indoleacetic acid, abscisic acid and pigments in variegated somaclones of micropropagated banana leaves. Journal of Plant Growth Regulation, v.17, p.59-61, 1998.

Received December 17, 2007

Accepted September 26, 2008 